\title{
PENGARUH PENGGUNAAN MODEL PICTURE AND PICTURE TERHADAP KEMAMPUAN MENULIS TEKS PROSEDUR SISWA KELAS VII SMP NEGERI 6 PARIAMA
}

\author{
Nurul Ikrima, Indriani Nisja, Lira Hayu Afdetis Mana \\ Program Studi Pendidikan Bahasa dan Sastra Indonesia STKIP PGRI Sumatera Barat \\ nurulikrima2310@gmail.com
}

\begin{abstract}
The study is set against the background of such problems as the following. Students are less interested in taking lessons. Students have not been able to write the textbook procedure according to the correct writing criteria. The study aims to describe the ability to write text of student procedure before and after using the picture and picture model and the effect the use of the picture and picture model on the ability to write the text of class procedure VII SMP N 6 Pariaman. This type of research is quantitative using experimental methods. The sample in this study were 25 students of class VII. The data in this study is the score of textual ability before using the picture and picture and text capability score of procedure after using the picture and picture class model VII SMP N 6 Pariaman. Based on research results may be summarized as follows. First, the ability to write the text procedure class VII SMP N 6 Pariaman before using a picture and picture model achieves an average of 66,85 with a qualification of more than Enough (LdC). Second, the students' ability to write procedural texts of class VII SMP N 6 Pariaman after using the Picture and Picture model obtained an average score of 76.18 with good qualifications (B). Third, based on the t-test, it is obtained tcount $=3.93>\mathrm{t}$ table $=1.71$. The test criteria for $\mathrm{t}$ is accepted, $\mathrm{t}$ count $>\mathrm{t}$ table, in other words $\mathrm{H} 1$ is accepted and $\mathrm{H} 0$ is rejected. Thus, the use of the Picture and Picture model has an effect on the ability to write the text of class procedure VII SMP N 6 Pariaman.
\end{abstract}

\section{Keywords :Writing, Procedure Text, Picture and Picture.}

\section{PENDAHULUAN}

Pembelajaran berbasis teks yang harus dikuasai siswa yaitu teks (1) teks deskripsi, (2) teks cerita fantasi, (3) teks prosedur, (4) teks laporan hasil observasi, (5) teks cerita fabel. Semua jenis teks tersebut adalah teks yang harus dikuasi siswa dalam semester 1 pada kelas VII dalam kurikulum 2013. Semakin banyak teks yang dikuasai siswa, semakin banyak pula pengetahuan keterampilan siswa dalam menulis teks. 
Salah satu pembelajaran menulis yang terdapat disekolah adalah teks prosedur. Teks prosedur merupakan teks yang memaparkan serta menjelaskan suatu informasi kepada pembaca.

Pembelajaran menulis teks prosedur terdapat pada kurikulum 2013 untuk tingkat SMP/MTs pada kompetensi inti (KI) 4.Mengolah, menalar, dan menyaji dalam ranah konkret dan ranah abstrak terkait dengan pengembangan dari yang dipelajarinya di sekolah secara mandiri, bertindak secara efektif dan kreatif, serta mampu menggunakan metode sesuai kaidah keilmuan. Kompetensi Dasar (KD) 4.6. Menyajikan data rangkaian kegiatan ke dalam bentuk teks prosedur (tentang cara memainkan alat musik daerah, tarian daerah, cara membuat cinderamata, dll) dengan memperhatikan struktur, unsur kebahasaan, dan isi secara lisan dan tulis. Kompetensi dasar tersebut berdasarkan teks prosedur siswa dituntut mampu menulis dan memperhatikan struktur dan kaidah kebahasannya. Sehubungan dengan rumusan $\mathrm{KI}$ dan $\mathrm{KD}$ tersebut, guru diharapkan mampu memaksimalkan kinerjanya untuk meningkatkan kemampuan siswa dalam menulis teks khususnya teks prosedur.

Keterampilan menulis siswa masih belum terlaksana dengan baik. Hal ini dapat dilihat dari hasil wawancara yang dilakukan pada tanggal 31 Agustus 2020 dengan seorang Guru Bahasa Indonesia di SMPN 6 Pariaman, yaitu Zawil Huda, S.Pd ditemukan beberapa permasalahan dalam menulis teks prosedur. Pertama, sikap siswa kurang responsif. Kedua, sebagian siswa memahami tentang struktur dan kebahasaannya namun sebagian lagi tidak paham untuk mengatasi siswa yang tidak memahami guru memberikan contoh teks prosedur yang bisa dijadikan model yang akan ditiru untuk dipahami. Ketiga, siswa sulit dalam menentukan struktur dan kebahasaannya.

Selanjutnya, wawancara juga dilakukan Ditemukan beberapa permasalahan yang dihadapi siswa dalam menulis teks prosedur, sebagai berikut. Pertama, siswa kesulitan 
menentukan struktur teks prosedur.

Kedua, siswa sulit untuk membuat tujuan teks prosedur. Ketiga, siswa sulit dalam menentukan kebahasaan teks prosedur.

Dari hasil wawancara tersebut, maka permasalahan dalam pembelajaran rendahnya minat kemampuan siswa tersebut, diperlukan penyajian materi yang bervariasi dalam pembelajaran menulis teks prosedur.

Salah satu cara yang dianggap tepat adalah dengan menggunakan model pembelajaran Picture And Picture. Model pembelajaran ini digunakan untuk memudahkan siswa dalam menguasai materi teks prosedur yang sudah diberikan dan menulis teks prosedur dengan lebih baik.

Model pembelajaran yang dapat diterapkan dalam kegiatan menulis teks prosedur adalah model picture and picture merupakan salah satu model yang bahannya berupa gambar-gambar. Melalui gambar, siswa bisa pendapatnya menyampaikan berpartisipasi langsung dalam proses pembelajaran.

Melalui model picture and picture ini, guru bisa menarik siswa untuk mampu menyusun gambar yang disiapkan oleh guru di depan kelas. Model pembelajaran picture and picture akan membantu siswa untuk bisa bekerja sama dalam memahami materi dan menghasilkan suatu karya baik.

Istarani (2014:7) mengatakan bahwa picture and picture merupakan suatu rangkaian penyampaian materi ajar dengan menunjukan gambar kongrit kepada siswa sehingga dapat memahami secara jelas tentang makna hakiki dari materi ajar yang disampaikan kepadanya. Selanjutnya Shoimin (2016:122), model pembelajaran picture and picture suatu model belajar menggunakan gambar dan dipasangkan menjadi urutan logis. Model pembelajaran gambar yang menjadi faktor utama dalam proses pembelajaran. Berdasarkan latarbelakang masalah di atas, maka penelitian ini bertujuan untuk mendeskripsikan kemampuan menulis teks prosedur siswa kelas VII SMPN 6 Pariaman dengan 
menggunakan model picture and picture siswa VII SMPN 6 Pariaman.

Keterampilan menulis sangat penting untuk dipelajari oleh siswa, melalui menulis siswa dapat menuangkan ide dan gagasan yang ada dalam pikiranya. Hal ini sejalan dnegan pendapat Dalman (2015:5), mengemukakan bahwa menulis merupakan suatu kegiatan komunikasi berupa penyampaian pesan (informasi) secara tertulis kepada pihak lain dengan menggunakan bahasa tulis sebagai alat atau medianya.

Priyatni (2014:87), menyatakan bahwa teks prosedur adalah teks yang memberikan petunjuk untuk melakukan atau menggunakan sesuatu dengan langkah-langkah yang urut. Teks prosedur menjelaskan fenomena buatan manusia dan bagaimana cara melakukannya.

Selanjutnya, Mahsun (2018:30) menyatakan teks prosedur merupakan salah satu dari jenis teks yang termasuk genre faktual subgenre prosedural. Tujuan sosial teks ini adalah mengarahkan atau mengajarkan tentang langkah-langkah yang telah ditentukan.

\section{METODE PENELITIAN}

Jenis penelitian ini adalah penelitian kuantitatif. Menurut Sugiyono (2014:23), penelitian kuantitatif merupakan penelitian yang dilakukan untuk meneliti populasi atau sampel tertentu. Pengumpulan data menggunakan intrumen penelitian. Metode yang digunakan dalam penelitian ini adalah metode eksperimen.

Populasi dalam penelitian ini adalah seluruh siswa kelas VII SMP Negeri 6 Pariaman yang terdaftar pada tahun 2020/2021, yang berjumlah 77 orang terdaftar dalam 3 kelas yaitu $\mathrm{VII}_{1}$ berjumlah 27 orang, kelas $\mathrm{VII}_{2}$ berjumlah 25 orang, dan kelas VII3 berjumlah 25. Sugiyono (2014:81), juga menambahkan bahwa sampel adalah bagian dari jumlah dan karakteristik yang dimiliki oleh populasi tersebut.

Pemilihan pengambilan sampel dilakukan dengan purposive sampling. 
Maka sampel dalam penelitian ini adalah siswa VII.2 yang berjumlah 25 orang.

Instrumen yang digunakan dalam penelitian ini adalah tes, Jenis tes unjuk kerja. Tes dilakukan dua kali, yaitu menilai keterampilan menulis teks prosedur sebelum dan menggunakan model Picture and Picture.

Teknik pengumpulan data dalam penelitian ini dilakukan dalam tiga kali pertemuan. Dengan langkah-langkah sebagai berikut: Pertemuan pertama, tes awal dilakukan dengan langkah-langkah berikut: (1) guru menyampaikan kompetensi yang akan dicapai. (2) guru menjelaskan materi teks prosedur. (3) siswa diberikan pretest (tes awal) menulis teks prosedur dengan tema "cinderamata dari kain flannel".

Pertemuan kedua dilakukan treatment (perlakuan). Guru memberikan perlakuan pada teks prosedur dengan tema"cinderamata dari batok kelapa" dengan menerapkan model Picture And Picture dengan langkah-langkah berikut: (1) Guru menjelaskan KD tentang membuat teks prosedur secara lisan/tulisan dengan memperhatikan struktur dan kebahasaan. (2) Guru menjelaskan materi tentang teks prosedur sebagai pengantar pembelajaran.

Guru memperlihatkan contoh gambar teks prosedur yang diacak. (4) Guru menunjukkan siswa / siswi secara bergantian untuk menyusun contoh gambar, sehingga menjadi susunan yang logis. (5) Guru menanyakkan alasan siswa / siswi tentang urutan gambar-gambarnya yang telah mereka urutan menjadikan urutan yang logis dari urutan gambar tersebut guru menugaskan masing-masing siswa untuk menulis teks prosedur. (6) Guru menambahkan penjelasan mengenai teks prosedur sesuai dengan kompetensi yang ingin dicapai. (7) Guru menyimpulkan pelajaran hari itu dan membuat rangkumannya.

$$
\text { Pertemuan ketiga, guru }
$$
memberikan tes akhir (postest) dengan langkah-langkah sebagai berikut: (1) siswa diberikan posttest (tes akhir) menulis teks prosedur dengan tema "cinderamata dari botol bekas". 
lembar kerja siswa dikumpul dan dinilai sesuai dengan indikator penilaian yang ada.

Setelah data dikumpulkan maka dilanjutkan dengan teknik anlisis data yang dimulai dari penskoran, penilaian dan menyimpulkan hasil penelitian yang telah dilakukan.

\section{HASIL DAN PEMBAHASAN}

Penelitian ini dilakukan pada tanggal 13 Januari 2021 pertemuan pertama, pertemuan kedua untuk perlakuan dilakukan pada tanggal 14 Januari 2021, dan pertemuan ketiga untuk tes akhir (posttest) dilakukan pada tanggal 16 Januari 2021. Hasil dan pembahasan dapat dilihat sebagai berikut ini

\section{Kemampuan Menulis Kembali Teks Prosedur sebelum Menggunakan Model Picture and Picture Siswa Kelas VII SMP N 6 Pariaman .}

Berdasarkan hasil penelitian maka kemampuan menulis kembali teks prosedur berkisar antara 52,3895,23. Secara lengkap, siswa yang memperoleh total nilai 52,38 sebanyak 5 orang siswa, siswa yang memperoleh total nilai 57,14 sebanyak 4 orang siswa, siswa yang memperoleh total nilai 61,90 sebanyak 5 orang siswa, siswa yang memperoleh total nilai 66,67 sebanyak 2 orang, siswa yang memperoleh total nilai 76,19 sebanyak 4 orang, siswa yang memperoleh nilai total 80,95 sebanyak 2 orang. Siswa yang memperoleh total nilai 85,71 sebanyak 1 orang, siswa yang memperoleh total nilai 90,47 sebanyak 1 orang, dan siswa yang memperoleh total nilai 95,23 sebanyak 1 orang.

Untuk lebih jelasnya dapat dilihat pada tabel di bawah ini.

Tabel 1. Frekuensi Frekuensi Kemampuan Menulis Teks Prosedur Sebelum Menggunakan Model Picture and Picture Siswa Kelas VII SMP N 6 Pariaman

\begin{tabular}{cccc}
\hline No & $\mathbf{X}$ & $\mathbf{F}$ & $\mathbf{F X}$ \\
\hline 1 & 52,38 & 5 & 261,9 \\
2 & 57,14 & 4 & 228,56 \\
3 & 61,90 & 5 & 309,5 \\
4 & 66,67 & 2 & 133,34 \\
5 & 76,19 & 4 & 304,76 \\
6 & 80,95 & 2 & 161,9 \\
7 & 85,71 & 1 & 85,71 \\
8 & 90,47 & 1 & 90,47 \\
9 & 95,23 & 1 & 95,23 \\
& Total & 25 & 1671,37 \\
\hline
\end{tabular}

Berdasarkan data di atas diperoleh rata-rata hitung (M) sebesar 66,85. Maka disimpulkan bahwa tingkat penguasaan kemampuan menulis teks prosedur sebelum menggunakan 
model Picture and Picture siswa kelas VII SMP N 6 Pariaman berada pada tingkat penguasaan 66 $75 \%$ berkualifikasi lebih dari cukup (Ldc).

Untuk masing-masing indikator dapat dijabarkan sebagai berikut.

Pertama, diperoleh nilai ratarata hitung pada aspek judul adalah 74,67 berada pada tingkat penguasaan $66-75 \%$ berkualifikasi lebih dari cukup (Ldc)

Kedua, nilai rata-rata hitung pada indikator tujuan adalah 69,33 berada pada tingkat penguasaan 66 $75 \%$ berkualifikasi lebih dari cukup $(\mathrm{LdC})$

Ketiga, nilai rata-rata hitung pada indikator bahan atau alat adalah 76 berada pada tingkat penguasaan $76-85 \%$ berkualifikas $\operatorname{baik}(\mathrm{B})$.

Keempat, nilai rata-rata hitung pada indikator prosedur atau tahapan adalah 82,67 berada pada tingkat penguasaan $\quad 76-85 \%$ berkualifikasi baik (B).

Kelima, nilai rata-rata hitung pada indikator penomoran adalah 61,33 berada pada tingkat penguasaan $56-65 \%$ berkualifikasi cukup (C).

Keenam, nilai rata-rata hitung pada indikator kata perintah 57,33 berada pada tingkat penguasaan 56$65 \%$ berkualifikasi cukup (C).

Ketujuh, nilai rata-rata hitung indikator menjelaskan kondisi 46,67 berada pada tingkat penguasaan 46$65 \%$ berkualifikasi hampir cukup (HC).

2. Kemampuan Menulis Kembali Teks Prosedur sesudah Menggunakan Model Picture and Picture Siswa Kelas VII SMP N 6 Pariaman .

Berdasarkan hasil penelitian maka kemampuan menulis kembali teks prosedur berkisar antara 61,90-95,23. Secara lengkap, siswa yang memperoleh total nilai 61,90 sebanyak 5 orang siswa, siswa yang memperoleh total nilai 66,67 sebanyak 4 orang siswa, siswa yang memperoleh total nilai 71,43 sebanyak 3 orang siswa, siswa yang memperoleh total nilai 76,19 sebanyak 2 orang, siswa yang memperoleh total nilai 80,95 sebanyak 2 orang, siswa yang memperoleh total nilai 85,71 sebanyak 2 orang. siswa yang 
memperoleh total nilai 90,47 sebanyak 5 orang, siswa yang memperoleh total nilai 95,23 sebanyak 2 orang.

Untuk lebih jelasnya dapat dilihat pada tabel di bawah ini.

Tabel 2. Frekuensi Frekuensi Kemampuan Menulis Kembali Teks Prosedur Sesudah Menggunakan Model Picture and Picture Siswa Kelas VII SMP N 6 Pariaman

\begin{tabular}{cccc}
\hline No & X & F & FX \\
\hline 1 & 61,90 & 5 & 247,6 \\
2 & 66,67 & 4 & 333,35 \\
3 & 71,42 & 3 & 214,26 \\
4 & 76,19 & 2 & 228,57 \\
5 & 80,95 & 2 & 161,9 \\
6 & 85,71 & 2 & 171,42 \\
7 & 90,47 & 5 & 452,35 \\
8 & 95,23 & 2 & 190,46 \\
& Jumlah & 25 & 1999,91 \\
\hline
\end{tabular}

Berdasarkan data di atas diperoleh rata-rata hitung (M) 80 . Maka disimpulkan bahwa tingkat penguasaan kemampuan menulis kembali teks prosedur sebelum menggunakan model pembelajaran Picture and Picture siswa kelas VII SMP N 6 Pariaman berada pada tingkat penguasaan 76-85\% berkualifikasi baik (B).

Pertama, diperoleh nilai ratarata hitung pada aspek judul adalah 68 berada pada tingkat penguasaan
66-75\% berkualifikasi lebih dari cukup (Ldc)

Kedua, nilai rata-rata hitung pada indikator tujuan adalah 85,33 berada pada tingkat penguasaan $76-85 \%$ berkualifikasi baik (B).

Ketiga, nilai rata-rata hitung pada indikator bahan atau alat adalah 89,33 berada pada tingkat penguasaan 8695\% berkualifikas baik sekali (BS).

Keempat, nilai rata-rata hitung pada indikator prosedur atau tahapan adalah 85,33 berada pada tingkat penguasaan $76-85 \%$ berkualifikasi baik (B).

Kelima, nilai rata-rata hitung pada indikator penomoran adalah 76,00 berada pada tingkat penguasaan 76$85 \%$ berkualifikasi baik (B).

Keenam, nilai rata-rata hitung pada indikator kata perintah 70,67 berada pada tingkat penguasaan 66$75 \%$ berkualifikasi lebih dari cukup $(\mathrm{LdC})$.

Ketujuh, nilai rata-rata hitung indikator menjelaskan kondisi 62,67 berada pada tingkat penguasaan 56$65 \%$ berkualifikasi cukup (C).

3. Pengaruh Penggunaan Model Picture and Picture terhadap Kemampuan Menulis Teks 
Prosedur Siswa Kelas X SMA N

4 Padang

Salah satu pembelajaran menulis teks pada siswa kelas VII yaitu menulis teks proseduri. Agar keterampilan menulis siswa dapat ditingkatkan maka dapat digunakan melalui salah satu model pembelajaran yang aktif dan inovatif.

Model pembelajaran yang dapat diguankan yaitu model Picture and Picture. Melalui model ini dapat meningkatkan kreatifitas siswa, karena model ini merupakan salah satu model yang dapat memaksimalka pikiran siswa.

Berdasarkan hasil analisis data penelitian yang dilakukan diketahui bahwa terdapat pengaruh yang signifikan penggunaan model Picture and Picture terhadap kemampuan menulis teks prosedur siswa kelas VII SMP N 6 Pariaman. Hal ini dibuktikan dengan hasil penelitian yang menunjukkan bahwa nilai $t_{\text {hitung }}(3,93)>t_{\text {tabel }}(1,71)$, sehingga hipotesis nol ditolak dan hipotesis alternatif diterima.
Berdasarkan nilai kemampuan menulis teks prosedur dengan menggunakan model Picture and Picture dalam pembelajaran lebih baik dibandingkan dengan sebelum menggunakan model Picture and picture. Hal ini terbukti dari nilai ratarata hitung kemampuan menulis berita sebelum menggunakan model Picture and Picture dikualifikasikan dengan lebih dari cukup. Dapat disimpulkan siswa kelas VII SMP N 6 Pariaman sebelum meggunakan model Picture and Picture belum menguasai materi tentang teks prosedur. Sedangkan, nilai rata-rata hitung kemampuan menulis prosedur sesudah menggunakan model Picture and Picture dikualifikasikan dengan lebih dari cukup. Dapat disimpulkan siswa kelas VII SMP N 6 Pariaman sesudah menggunakan model Picture and Picture telah menguasai materi tentang menulis teks prosedur.

Berdasarkan hasil penelitian tersebut terlihat bahwa penggunaan model Picture and Picture lebih baik digunakan dalaam pembelajaran menulis teks prosedur siswa. Model pembelajaran Picture and Picture 
dapat menumbuhkan semangat siswa dalam belajar. Materi yang diberikan menjadi mengesankan dan selalu diingat siswa.

Hasil penelitian terdahulu juga menjelaskan bahwa penggunaan model Picture and Picture dapat meningkatkan kemampuan menulis siswa, seperti penelitian yang dilakukan oleh Putri (2017) dengan judul penelitian "Pengaruh Penggunaan Model Pembelajaran Picture and Picture. Terhadap Keterampilan Menulis Teks Negosiasi Siswa Kelas X SMA. Hasil penelitian menunjukan bahwa terdapat pengaruh penggunaan model Picture and Picture terhadap keterampilan menulis teks negoisasi siswa.

Model pembelajaran Picture and Picture juga mendorong siswa lebih kompetitif serta memberikan semangat untuk lebih maju, sehingga melalui penerapan model ini dapat meningkatkan kemampuan menulis siswa.

\section{KESIMPULAN}

Berdasarkan deskripsi data, analisis data, dan pembahasan maka dapat disimpulkan bahwa. Pertama, kemampuan menulis teks prosedursiswa kelas VII SMP N 6 Pariaman sebelum menggunakan model Picture and Picture memperoleh nilai rata-rata 66,85 berada pada rentangan $66-75 \%$ dengan kualifikasi yaitulebih dari Cukup (LdC). Kedua, kemampuan menulis teks prosedur siswa kelas VII SMP N 6 Pariaman sesudah menggunakan model Picture and Picture memperoleh nilai rata-rata 76,18 berada pada rentangan $76-85 \%$ dengan kualifikasi yaitu baik (B).

Ketiga, berdasarkan uji-t terdapat pengaruh model terhadap kemampuan menulis teks prosedur siswa kelas VII SMP N 6 Pariaman karena $t_{\text {hitung }}=$ 3,93 dan $t_{\text {tabel }}=1,71$ kriteria pengujian $t$ diterima jika $t_{\text {hitung }}>t_{\text {tabel }}$ dengan kata lain $\mathrm{H}_{1}$ diterima dan $\mathrm{H}_{0}$ ditolak. Degan demikian penggunaan model Picture and Picture berpengaruh terhadap kemampuan menulis teks prosedur siswa kelas VII SMP N 6 Pariaman. 


\section{DAFTAR PUSTAKA}

Dalman. 2015. Keterampilan Menulis. Jakarta: Rajawali Pers.

Istarani. 2014. 58 Model Pembelajaran Inovatif. Medan:Media Persada.

Mahsun, 2018. Pembelajaran Bahasa Indonesia Berbasis Teks. Depok: Rajawali Pers.

Priyatni, Endah Tri. 2014. Desain Pembelajaran Bahasa Indonesia Dalamkurikulum 2013. Jakarta: PT Bumi Aksara.

Sugiyono. 2014Metode Penelitian Kuantitatif Kualitatif dan $R \& D$. Bandung: Alfabeta.

Shoimin, Aris. 2016. 68 Model Pembelajaran Inovatif dalam Kurikulum 2013. Yogyakarta: Ar-Ruzz Media. 